\title{
Kebijakan Hukum dalam Upaya Penanggulangan Tindak Pidana Kecelakaan Lalu Lintas yang Mengakibatkan Matinya Korban
}

\section{Legal Policy in The Effort to Manage Criminal Acts of Traffic Accidents That Cause the Death of The Victims}

\author{
Dahnial Saragih, Taufik Siregar \& Rizkan Zulyadi*
}

Program Magister Hukum Pascasarjana, Universitas Medan Area, Indonesia Diterima: 09 Agustus 2021; Direview: 15 Agustus 2021; Disetujui: 07 Oktober 2021

*Coresponding Email: rizkanzulyadi@staff.uma.ac.id

\section{Abstrak}

Permasalahan lalu lintas merupakan salah satu masalah yang berskala nasional yang berkembang seirama dengan perkembangan masyarakat. Masalah yang dihadapi dewasa ini adalah masih tingginya angka kecelakaan lalu lintas di jalan raya. Penelitian ini bertujuan untuk mengetahui pertanggungjawaban dan kebijakan hukum dalam upaya penanggulangan pelaku tindak pidana kecelakaan lalu lintas yang mengakibatkan matinya korban di Sat.Lantas Polres Humbang Hasundutan. Metode penelitian yang digunakan adalah jenis penelitian hukum yuridis normatif atau doktriner sebagai penelitian perpustakaan atau studi dokumen, yang memiliki sifat deskripstif analisis. Hasil penelitian menunjukkan bahwa aturan hukum terhadap pelaku tindak pidana kecelakaan lalu lintas yang mengakibatkan matinya korban diatur pada Pasal 359 Kitab Undang-Undang Hukum Pidana, Pasal 106 ayat (2), Pasal 229, Pasal 310 ayat 1 sampai 4 dan Pasal 312 Undang- Undang No. 22 Tahun 2009 tentang Lalu Lintas dan Angkutan Jalan dan Peraturan Pemerintah Nomor 37 Tahun 2017 Tentang Keselamatan Lalu lintas dan Angkutan Jalan. Kebijakan hukum dalam upaya penanggulangan tindak pidana kecelakaan lalu lintas yang mengakibatkan matinya korban di Sat.Lantas Polres Humbang Hasundutan dilakukan secara Penal dan Non Penal dimana pertanggungjawaban dilakukan dengan menerapkan hukuman pidana penjara yang diatur sesuai Pasal 310 ayat (4) Undang- Undang No. 22 Tahun 2009 tentang Lalu Lintas dan Angkutan Jalan.

Kata Kunci: Kebijakan Hukum; Kecelakaan Lalu Lintas; Matinya Korban

\begin{abstract}
Traffic problems are one of the problems on a national scale that develop in tune with the development of society. The problem faced today is the high number of traffic accidents on the highway. This study aims to determine the accountability and legal policies in an effort to overcome the perpetrators of traffic accidents that resulted in the death of the victim at the Humbang Hasundutan Police Traffic Unit. The research method used is normative or doctrinal juridical legal research as library research or document study, which has descriptive analysis. The results of the study indicate that the law against perpetrators of traffic accidents resulting in the death of the victim is regulated in Article 359 of the Criminal Code, Article 106 paragraph (2), Article 229, Article 310 paragraphs 1 to 4 and Article 312 of the Law. No. 22 of 2009 concerning Road Traffic and Transportation and Government Regulation Number 37 of 2017 concerning Traffic and Road Transportation Safety. Legal policy in an effort to overcome the crime of traffic accidents that resulted in the death of the victim at the Humbang Hasundutan Sat.Lantas Police carried out penal and non-penal where accountability is carried out by applying imprisonment as regulated in Article 310 paragraph (4) of Law no. 22 of 2009 concerning Road Traffic and Transportation.
\end{abstract}

Keywords: Legal Policy; Traffic Accident; Death of The Victim.

How to Cite: Saragih. D. Siregar, T., \& Zulyadi, R. (2021). Kebijakan Hukum Dalam Upaya Penanggulangan Tindak Pidana Kecelakaan Lalu Lintas Yang Mengakibatkan Matinya Korban. Journal of Education, Humaniora and Social Sciences (JEHSS). 4 (2): 1234-1245. 


\section{PENDAHULUAN}

Lalu lintas merupakan salah satu sarana komunikasi masyarakat yang memegang peranan sangat vital dalam memperlancar pembangunan yang kita laksanakan. Masalah lalu lintas merupakan salah satu masalah yang berskala nasional yang berkembang seirama dengan perkembangan masyarakat. Masalah yang dihadapi dewasa ini adalah masih tingginya angka kecelakaan lalu lintas di jalan raya.

Pelanggaran lalu lintas yang banyak dilakukan oleh pengguna kendaraan bermotor antara lain mengemudi kendaraan bermotor tanpa dilengkapi surat tanda nomor kendaraan bermotor, atau pun tidak memiliki surat izin mengemudi, melanggar ketentuan rambu-rambu lalu lintas, tidak menggunakan helm standar bagi pengendara sepeda motor, mengemudikan kendaraaan bermotor dengan kecepatan yang melampaui batas dan lain sebagainya (Nurfauziah \& Krisnani, 2021). Hal ini membuktikan bahwa masyarakat kita masih kurang kasadaran hukumnya, padahal aturan-aturan tersebut dibuat demi keamanan dan kenyamanan dan keselamatan masyarakat pada umumnya dan khususnya pengendara kendaraan bermotor.

Kecelakaan lalu lintas yang terjadi antara lain disebabkan oleh kelelahan, kelengahan, kekurangan hati-hatian, dan kelalaian yang dialami pengemudi. Tidak berlebihan semua kecelakaan lalu lintas yang melibatkan kendaraan pribadi maupun kendaraan umum disebabkan oleh faktor pengemudi, pejalan kaki, kendaraan, sarana dan prasarana, petugas / penegak hukum dalam lalu lintas jalan. Faktor kecelakaan lalu lintas yang sering terjadi dikarenakan human erro (faktor manusia) (Sodikin, 2007).

Perkara kecelakaan merupakan bagian dari tindak pidana kealpaan yang disebutkan dalam Pasal 359 KUHPidana (Kitab Undang-Undang Hukum Pidana). Dalam Pasal 359 KUHPidana (Kitab Undang-Undang Hukum Pidana) ditegaskan dengan dua cara bahwa kematian orang lain adalah akibat dari kelalaian pembuat, yaitu dengan tidak menyebutkan pembuat tetapi kesalahannya (kealpaannya). Dalam situasi pengendara kenadara bermotor, salah berbuat dan tidak berbuat seakan-akan menjadi satu perbuatan (Hatta, 2012).

Akibat hukum dari kecelakaan lalu lintas adalah adanya pidana bagi si pembuat atau penyebab terjadinya peristiwa itu dan dapat pula disertai tuntutan perdata atas kerugian material yang ditimbulkan. Sebagaimana dinyatakan oleh Andi Hamzah, bahwa "Dalam berbagai macam kesalahan, di mana orang yang berbuat salah menimbulkan kerugian pada orang lain, maka ia harus membayar ganti kerugian" (Hamzah, 2009). Hukum sebagai konfigurasi peradaban manusia berjalan seiring dengan pertumbuhan dan perkembangan masyarakat sebagai komunitas dimana manusia tumbuh dan berkembang pula. Namun belakangan ini, terjadi berbagai distorsi perubahan dalam masyarakat Indonesia yang kemudian dikenal sebagai krisis moral (Hamzah, 2008).

Permasalahan di bidang lalu lintas disebabkan oleh masyarakat yang kurang peduli terhadap terciptanya ketertiban berlalu lintas dan kurang paham mekanisme penyelesaian perkara pelanggaran lalu lintas yang secara sadar maupun tidak sadar kurang melakukan pengawasan kepada setiap kendaraan bemotor yang menyalahi aturan dan tidak mempunyai dokumen yang lengkap sehingga layak untuk beredar di jalan raya. Banyak sekali dijumpai permasalahan yang berkaitan dengan pelanggaran hukum, mulai dari yang ringan hingga yang berat (Prodjodikoro, 2013).

Pelanggaran ringan yang kerap terjadi dalam permasalahan lalu lintas adalah seperti tidak memakai helm, menerobos lampu merah, tidak memiliki SIM atau STNK, tidak menghidupkan lampu pada siang hari, dan bonceng tiga dianggap sudah membudaya di kalangan masyarakat dan anak-anak sekolah. Pelanggaran lalu lintas seperti itu dianggap sudah menjadi kebiasaan bagi masyarakat pengguna jalan, sehingga tiap kali dilakukan operasi tertib lalu lintas di jalan raya oleh pihak yang berwenang, maka tidak sedikit yang terjaring kasus pelanggaran lalu lintas dan tidak jarang juga karena pelanggaran tersebut kerap menimbulkan kecelakaan lalu lintas.

Beberapa kecelakaan lalu lintas yang terjadi, sebenarnya dapat dihindari bila di antara pengguna jalan bisa berprilaku disiplin, sopan dan saling menghormati (Suharjo, 2012).

hww http://mahesainstitute.web.id/ojs2/index.php/jehss

Nmahesainstitut@gmail.com 1235

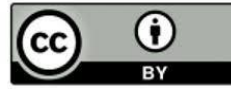

This work is licensed under a Creative Commons Attribution 4. 
Beberapa kecelakaan lalu lintas yang terjadi, sebenarnya dapat dihindari bila di antara pengguna jalan mematuhi peraturan yang diatur di dalam Undang-Undang No. 22 Tahun 2009 tentang Lalu Lintas dan Angkutan Jalan, khususnya Pasal 105 dan Pasal 106, menyebutkan bahwa: Dimana penggunaan jalan tersebut di atur dalam Undang-Undang No. 22 Tahun 2009 tentang Lalu Lintas dan Angkutan Jalan.

Dalam hal kecelakaan lalu lintas ada 2 (dua) hal yang dapat dilihat untuk dibahas dalam penelitian ini, yaitu: sanksi kesengajaan dan sanksi kelalaian. Kedua sanksi tersebut adalah resiko bagi pengendara yang dapat memicu kecelakaan lalu lintas. Dalam Undang-Undang No. 22 Tahun 2009 tentang Lalu Lintas dan Angkutan Jalan disebutkan, sanksi bagi pengendara lalai menyebabkan kematian orang lain dapat dijerat dengan pidana penjara hingga maksimal 12 (dua belas) tahun atau sanksi denda maksimal Rp. 24.000.000,- (dua puluh empat juta rupiah). Menurut uraian Pasal 310 Undang-Undang No. 22 Tahun 2009 tentang Lalu Lintas dan Angkutan Jalan dapat disimpulkan bahwa apabila kealpaan atau kelalaian pengemudi itu mengakibatkan orang lain terluka atau meninggal dunia ancaman pidananya sebagaimana yang diatur dalam ketentuan tersebut di atas. Meskipun Undang-Undang No. 22 Tahun 2009 tentang Lalu Lintas dan Angkutan Jalan telah diterapkan tetapi tidak dapat dipungkiri bahwa tingkat kecelakaan masih tetap terjadi.

Dengan banyaknya kasus kecelakaan di jalan raya setidaknya dapat menggambarkan cerminan masyarakat betapa minimnya kesadaran hukum bagi pengendara sepeda motor. Pasal 310 Undang-Undang No. 22 Tahun 2009 tentang Lalu Lintas dan Angkutan Jalan adalah khusus sanksi bagi pengemudi yang lalai (Sulistiono, 2016). Dalam berlalu lintas juga dikenal dengan adanya kesengajaan dan kelalaian. Kebanyakan rumusan tindak pidana, unsur kesengajaan atau yang disebut dengan opzet merupakan salah satu unsur yang terpenting. Kaitannya dengan unsur kesengajaan ini, maka apabila di dalam suatu rumusan tindak pidana terdapat perbuatan dengan sengaja atau biasa disebut dengan opzettelijk, maka unsur dengan Karena masih banyak orangorang yang mengemudi tidak tertib dan taat pada rambu-rambu lalu lintas.

Berkendara dengan menggunakan mobil maupun dengan sepeda motor di kota-kota besar yang memiliki traffic lalu lintas super sibuk tentu saja bukan hal yang mudah dan nyaman. Selain direpotkan oleh kemacetan yang semakin hari semakin menjadi-jadi, kita juga sering disuguhi dengan sebagian aksi pengendara "kuda besi" yang masih memiliki tingkat kesadaran keselamatan berkendara yang rendah. Efek ini selain semakin menambah faktor kecelakaan lalu lintas, juga akan memunculkan efek domino yang semakin hari dianggap sebagai kebiasaan lalu lintas sehari-hari. Bahkan tak jarang, membuat kita menjadi tidak nyaman saat berkendara di jalan raya (Raharjo, 2014)

Berkembangnya kecelakaan lalu lintas yang terjadi Satuan Lalu Lintas (Satlantas) Polres Humbang Hasundutan (Humbahas) sebanyal 147 kasus angka kecelakaan lalu lintas dan 6.079 pelanggaran lalu lintas di wilayah hukum Polres Humbahas pada tahun 2018-2020. "Polres Humbahas akan menekan angka kecelakaan dengan melaksanakan berbagai kegiatan operasi rutin di lapangan," kata Kasubbag Humas Polres Humbahas, Bripka Syawal B.Lolobako, Selasa. Kecelakaan umumnya diakibatkan kelalaian pengendara dan kurang memperhatikan ramburambu lalu lintas. Dihimbau agar pengendara menjadi pelopor berlalu lintas.

Berdasarkan uaraian di atas penelitian ini bertujuan untuk mengkaji dan menganalisis aturan hukum, pertanggungjawaban dan kebijakan hukum dalam upaya penanggulangan tindak pidana kecelakaan lalu lintas yang mengakibatkan matinya korban di Sat.Lantas Polres Humbang Hasundutan.

\section{METODE PENELITIAN}

Jenis penelitian yang digunakan adalah penelitian hukum yaitu penelitian yang dilakukan dengan meneliti bahan pustaka (data sekunder) atau penelitian hukum perpustakaan yang meliputi penelitian terhadap asas-asas hukum; penelitian terhadap sistematika hukum; penelitian terhadap taraf sinkronisasi vertikal dan horizontal; penelitian perbandingan hukum; dan penelitian sejarah hukum (Ediwarman, 2016). Sifat penelitian ini adalah deskriptif analitis 
yang dilakukan berdasarkan gambaran, fakta yang diperoleh dan akan dilakukan secara cermat bagaimana menjawab permasalahan dalam menyimpulkan suatu solusi sebagai jawaban dari permasalahan tersebut (Wijayanti, 2011). Pendekatan yang digunakan di dalam penelitian hukum adalah pendekatan undang-undang, pendekatan kasus. Pendekatan undang-undang dilakukan dengan menelaah semua undang-undang dan regulasi yang bersangkut paut dengan isu hukum yang ditangani dan pendekatan kasus dilakukan dengan cara melakukan telaah kasuskasus yang berkaitan dengan isu yang dihadapi yang telah menjadi putusan pengadilan yang telah mempunyai kekuatan hukum tetap (Marzuki, 2011).

Pendekatan yang digunakan dalam penelitian ini adalah berdasarkan pendekatan berdasarkan kasus yang terjadi tentang tindak pidana kecelakaan lalu lintas yang mengakibatkan matinya korban, serta pendekatan undang-undang berdasarkan Undang-Undang No. 22 Tahun 2009 tentang Lalu lintas dan Angkutan Jalan. Alat pengumpul data yang digunakan adalah dengan studi kepustakaan atau studi dokumen (Documentary Study) dengan mempergunakan sumber hukum data sekunder. Data sekunder adalah data yang diperoleh peneliti dari penelitian kepustakaan dan dokumen, yang merupakan hasil penelitian dan pengolahan orang lain, yang sudah tersedia dalam bentuk buku-buku atau dokumen yang biasanya disediakan diperpustakaan atau milik pribadi (Hadikusuma, 2006).

Prosedur pengambilan dan pengumpulan data dalam penelitian ini dilakukan dengan cara penelitian kepustakaan (Library Research) yaitu dengan melakukan penelitian terhadap berbagai sumber bacaan yaitu buku-buku, peraturan undang-undang, majalah hukum, pendapat para sarjana, dan juga bahan-bahan kuliah.Selanjutnya dilakukan penelitian lapangan (Field Research) yakni dengan melakukan penelitan kelapangan dengan mengambil kasus tindak pidana kecelakaan lalu lintas yang mengakibatkan matinya korban di Satuan Lalu Lintas Polres Humbang Hasundutan untuk dianalisis. Analisis data merupakan langkah terakhir dalam suatu kegiatan penulisan. Analisis data dilakukan secara kualitatif yaitu penelitian tentang riset yang bersifat deskripstif dan cenderung menggunakan analisis, proses dan makna yang lebih diutamakan. Dalam penelitian kualitatif landasan teori dimanfaatkan sebagai pemandu agar fokus penelitian sesuai dengan fakta dilapangan (Nasution, 2011).

\section{HASIL DAN PEMBAHASAN}

\section{Aturan Hukum Pidana Kecelakaan Lalu Lintas Yang Mengakibatkan Matinya Korban Menurut Kitab Undang-Undang Hukum Pidana}

Ketentuan-ketentuan mengenai kelalaian atau kealpaan yang menyebabkan korbannya meninggal dunia diatur dalam Kitab Undang-Undang Hukum Pidana (KUHP) Buku kedua tentang kejahatan Bab XXI Pasal 359, yang berbunyi sebagai berikut (Lihat Pasal 359 Kitab UndangUndang Hukum Pidana): "Barang siapa karena kealpaannya menyebabkan matinya orang lain, diancam dengan pidana penjara paling lama 5 (lima) tahun atau kurungan paling lama 1 (satu) tahun". Adapun Unsur-unsur dari rumusan Pasal 359 KUHPidana tersebut di atas, yaitu:

Barang siapa. Yang dimaksud dengan barang siapa adalah untuk menentukan siapa pelaku delik sebagai subjek hukum yang telah melakukan delik tersebut dan memiliki kemampuan mempertanggungjawabkan perbuatannya. Dalam hal ini maksud dari pada subjek hukum yang memiliki kemampuan bertanggungjawab adalah didasarkan kepada keadaan dan kemampuan jiwa dari pelaku yang didakwakan melakukan delik (Syarifin, 2010)

Karena kelalaian. Dalam unsur ini, bahwa matinya korban merupakan akibat dari kelakuan yang tidak dikehendaki oleh terdakwa (orang yang berbuat). Van Hamel berpendapat, bahwa kealpaan (culpa) mengandung 2 (dua) syarat, yaitu (Moeljatno, 2015): Tidak mengadakan duga-dugaan sebagaimana diharuskan oleh hukum; Tidak mengadakan kehati-hatian sebagaimana diharuskan oleh hukum.

Menyebabkan matinya orang lain. Dalam perbuatan menghilangkan nyawa (orang lain) terdapat 3 (tiga) syarat yang harus dipenuhi, yaitu (Hamzah 2008). Adanya wujud dari perbuatan; Adanya suatu kematian (orang lain); Adanya hubungan sebab dan akibat (causal verband) antara perbuatan dengan akibat kematian orang lain.

wwithttp://mahesainstitute.web.id/ojs2/index.php/jehss

Nmahesainstitut@gmail.com 1237

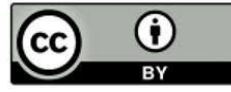

This work is licensed under a Creative Commons Attribution 4. 
Matinya orang dalam Pasal 359 KUHPidana ini tidak dimaksudkan sama sekali oleh terdakwa, akan tetapi kematian tersebut hanya merupakan akibat dari pada kurang hati-hati atau lalainya terdakwa (culpa), maka pelaku tidak dikenakan pasal tentang pembunuhan (Pasal 338 dan Pasal 340 KUHPidana). Pasal 359 KUHPidana ini menjelaskan bahwa kematian orang lain adalah akibat dari kelalaian sipembuat dengan tidak menyebutkan perbuatan sipembuat tetapi kesalahannya. Selanjutnya dalam Pasal 360 KUHPidana, dinyatakan bahwa: Barang siapa karena kelalaiannya menyebabkan orang luka berat dihukum dengan hukuman penjara selama-lamanya 5 (lima) tahun atau hukuman kurungan selama-lamanya 1 (satu) tahun. Barang siapa karena kelalaiannya menyebabkan orang luka sedemikian rupa sehingga orang itu menjadi sakit sementara atau tidak menjalankan jabatannya atau pekerjaannya sementara, dihukum dengan hukuman penjara selama-lamanya 9 (sembilan) bulan atau hukuman kurungan selama-lamanya 6 (enam) bulan atau hukuman denda setinggi-tingginya Rp. 4.500,-.

Pasal 360 KUHPidana ini berkaitan dengan Pasal 359 KUHPidana, bedanya bahwa akibat dari Pasal 359 KUHPidana adanya "Matinya orang", sedangkan akibat dalam Pasal 360 KUHPidana adalah ayat (1) mengenai luka berat dan ayat (2) akibatnya adalah luka sedemikian rupa. Adapun unsur-unsur dari Pasal 360 KUHPidana tersebut diatas, yaitu: barang siapa; karena kelalaian; menyebabkan orang lain luka. Terlukanya orang lain dapat berupa luka ringan dan luka berat. Luka berat dapat dilihat sebagaimana diatur dalam Pasal 90 KUHPidana, yaitu: Jatuh sakit atau mendapat luka yang tidak memberi harapan akan sembuh sama sekali atau yang menimbulkan bahaya maut; Tidak mampu terus menerus untuk menjalankan tugas jabatan atau pekerjaan pencarian; Kehilangan salah satu panca indera; Mendapat cacat berat; Menderita sakit lumpuh; Terganggunya daya pikir selama empat minggu lebih; Gugurnya atau matinya seorang perempuan.

\section{Kebijakan Hukum Pidana Kecelakaan Lalu Lintas Yang Mengakibatkan Matinya Korban Menurut Undang-Undang No. 22 Tahun 2009 Tentang Lalu Lintas dan Angkutan Jalan.}

Undang-Undang Nomor 22 Tahun 2009 Tentang Lalu Lintas dan Angkutan Jalan secara tegas mengatur tentang tanggung jawab Pengemudi dan/atau Pemilik Kendaraan Bermotor terhadap peristiwa kecelakaan lalu lintas yang melibatkan mereka. Apabila korban meninggal dunia akibat kecelakaan lalu lintas sebagaimana dimaksud dalam Pasal 229 ayat (1) huruf c, pengemudi, dan/atau pemilik kendaraan bermotor dan/atau perusahaan angkutan umum wajib memberikan bantuan kepada Ahli Waris dari korban berupa biaya pengobatan dan/atau biaya pemakaman dengan tidak menggugurkan tuntutan perkara Pidana; Apabila korban terjadi cedera terhadap badan atau kesehatan korban akibat kecelakaan lalu lintas sebagaimana pengemudi, pemilik kendaraan bermotor, dan/atau perusahaan angkutan umum wajib memberikan biaya pengobatan dengan tidak menggugurkan tuntutan perkara Pidana.

Undang-undang ini juga memberikan pengecualian, yaitu apabila pengemudi dan/atau pemilik kendaraan bermotor tidak wajib memberikan biaya kepada korban dan/atau ahli waris korban, apabila peristiwa kecelakaan lalu lintas itu terjadi karena adanya keadaan memaksa yang tidak dapat dielakkan atau diluar kemampuan, disebabkan prilaku korban sendiri atau pihak ketiga, maupun disebabkan gerakan orang dan/atau hewan walaupun telah diambil tindakan pencegahan (Lihat Pasal 234 ayat 3 Undang-undang Nomor 22 Tahun 2009 Tentang Lalu Lintas dan Angkutan Jalan). Pengertian keadaan memaksa dalam hal ini adalah peristiwa yang tidak dapat dielakkan atau diluar kemampuan pengemudi untuk mengelakkan kejadian kecelakaan lalu lintas.

Lalu lintas dan angkutan jalan merupakan hal yang sangat penting dalam meningkatkan mobilitas sosial masyarakat. Sehingga negara merasa penting untuk mengaturnya sesuai dengan perkembangan zaman agar hak-hak warga negara dalam kegiatan lalu lintas dan angkutan jalan tetap terjaga dan terjamin. Undang-Undang Nomor 22 Tahun 2009 Tentang Lalu Lintas dan Angkutan Jalan Raya merupakan produk hukum yang menjadi acuan dasar dan utama yang mengatur segala bentuk aspek lalu lintas dan angkutan jalan di Indonesia (Anis Febriani, 2019).

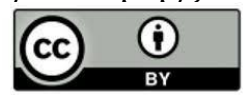


Undang-undang ini merupakan penyempurnaan dari undang-undang sebelumnya yaitu Undang-Undang Nomor 14 Tahun 1992 Tentang Lalu Lintas dan Angkutan Jalan Raya yang mana undang-undang ini dinilai sudah tidak sesuai lagi dengan kondisi, perubahan lingkungan strategis, kebutuhan penyelenggaraan lalu lintas dan angkutan jalan saat ini, sehingga perlu diganti dengan undangundang yang baru. Undang-Undang Nomor 22 Tahun 2009 Tentang Lalu Lintas dan Angkutan Jalan telah ditetapkan dalam Rapat Paripurna DPR RI pada tanggal 26 Mei 2009 yang kemudian disahkan oleh Presiden RI pada tanggal 22 Juni 2009. Undang-undang ini adalah kelanjutan dari Undang-Undang Nomor 14 Tahun 1992, terlihat bahwa kelanjutannya merupakan pengembangan yang signifikan dilihat dari jumlah klausul yang diaturnya, yakni yang sebelumnya berjumlah 16 bab dan 74 pasal, menjadi 22 bab dan 326 pasal.

Undang-Undang Nomor 14 Tahun 1992 dengan Undang-Undang Nomor 22 Tahun 2009 memiliki beberapa perbedaan, yaitu undang-undang yang awal, yakni Undang-Undang Nomor 14 Tahun 1992 menyebutkan bahwa untuk mencapai tujuan pembangunan nasional sebagai pengamalan Pancasila, transportasi memiliki posisi yang penting dan strategis dalam pembangunan bangsa yang berwawasan lingkungan dan hal ini harus tercermin pada kebutuhan mobilitas seluruh sektor dan wilayah.

Transportasi merupakan sarana yang sangat penting dan strategis dalam memperlancar roda perekonomian, memperkukuh persatuan dan kesatuan serta mempengaruhi semua aspek kehidupan bangsa dan negara (Anis Febriani). Undang-Undang Nomor 22 Tahun 2009, undangundang ini memandang bahwa lalu lintas dan angkutan jalan mempunyai peran strategis dalam mendukung pembangunan dan integrasi nasional sebagai bagian dari upaya untuk memajukan kesejahteraan umum, kemudian pada batang tubuh undang-undang tersebut dijelaskan bahwa tujuan yang hendak dicapai oleh undang-undang ini diantaranya:

a. Terwujudnya pelayanan lalu lintas dan angkutan jalan yang aman, selamat, tertib, lancar, dan terpadu dengan moda angkutan lain untuk mendorong perekonomian nasional, memajukan kesejahteraan umum, memperkukuh persatuan dan kesatuan bangsa, serta mampu menjunjung tinggi martabat bangsa,

b. Terwujudnya etika berlalu lintas dan budaya bangsa, dan

c. Terwujudnya penegakan hukum dan kepastian hukum bagi masyarakat.

Undang-undang ini berlaku untuk membina dan menyelenggarakan lalu lintas dan angkutan jalan yang aman, tertib, selamat, dan lancar yang ditempuh melalui kegiatan gerak pindah kendaraan, orang, dan/atau barang di jalan, kegiatan yang menggunakan sarana, prasarana, dan fasilitas pendukung lalu lintas dan angkutan jalan, dan kegiatan yang berkaitan dengan registrasi dan identifikasi kendaraan bermotor dan pengemudi, pendidikan berlalu lintas, manajemen dan rekayasa lalu lintas, serta penegakan hukum lalu lintas dan angkutan jalan.

Rekayasa lalu lintas dimaksud meliputi kegiatan perencanan, pengaturan, pengawasan, dan pengendalian lalu lintas. Program Nasional "Keselamatan Lalu Lintas dan Angkutan Jalan" (KLLAJ) terdiri atas 5 (lima) pilar keselamatan yang meliputi (Lihat Pasal 3 ayat (3) Peraturan Pemerintah Nomor 37 Tahun 2017 Tentang Keselamatan Lalu lintas dan Angkutan Jalan): Pilar 1 (satu) yaitu sistem yang berkeselamatan; Pilar 2 (dua) yaitu jalan yang berkeselamatan; Pilar 3 (tiga) yaitu kendaraan yang berkeselamatan; Pilar 4 (empat) yaitu pengguna jalan yang berkeselamatan; dan Pilar 5 (lima) yaitu penanganan korban kecelakaan.

Sedangkan pengaturan lalu lintas meliputi kegiatan penetapan kebijakan lalu lintas pada jaringan atau ruas-ruas jalan tertentu. Pengawasan lalu lintas meliputi: Pemantauan dan penilaian terhadap pelaksanan kebijakan lalu lintas di bidang pengaturan lalu lintas; Tindakan korektif terhadap pelaksanan kebijakan lalu lintas di bidang pengaturan lalu lintas pengendalian lalu lintas meliputi; Pemberian arahan dan petunjuk dalam pelaksanan kebijakan lalu lintas dalam bidang pengaturan lalu lintas; Pemberian bimbingan dan penyuluhan kepada masyarakat mengenai hak dan kewajiban masyarakat dalam pelaksanan kebijakan lalu lintas dalam bidang pengaturan lalu lintas.

Selain diatur mengenai kegiatan-kegiatan yang harus dilakukan dalam kebijakan manajemen dan rekayasa lalu lintas, juga telah diatur secara terperinci mengenai kegiatanwww http://mahesainstitute.web.id/ojs2/index.php/jehss 1239

Nahesainstitut@gmail.com

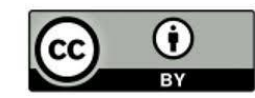

This work is licensed under a Creative Commons Attribution 4. 
kegiatan yang harus dilakukan atau dipatuhi oleh setiap pengemudi/pengendara kendaraan bermotor di jalan raya, antara lain, menyangkut penggunaan jalur jalan, gerakan lalu lintas kendaraan bermotor, kelengkapan kendaraan bermotor, kelengkapan pengemudi bermotor dalam administrasi surat izin mengemudi, kendaraan berhenti dan parkir, kecepatan maksimum dan/atau minimum kendaraan bermotor. Perusahaan Angkutan Umum wajib membuat, melaksanakan, dan menyempurnakan Sistem Manajemen Keselamatan Perusahaan Angkutan Umum dengan berpedoman pada "Rencana Umum Nasional Keselamatan Lalu Lintas dan Angkutan Jalan” (RUNK LLAJ) (Simanjuntak, 2016).

\section{Pertanggungjawaban Pelaku Tindak Pidanakecelakaan Lalu Lintas Yang Mengakibatkan Matinya Korban Di Sat.Lantas Polres Humbang Hasundutan.}

Kecelakaan (accident) adalah kejadian yang tak terduga dan tidak diharapkan. Kecelakaan lalu lintas adalah kejadian di mana sebuah kendaraan bermotor tabrakan dengan benda lain dan menyebabkan kerusakan. Kata "kecelakaan" memiliki kata dasar "celaka". Kata celaka dapat diartikan dalam Kamus Umum Bahasa Indonesia yang berarti Menderita sesuatu yang menyusahkan, malang, sial tidak beruntung, tidak berbahagia. Sehubungan dengan hal tersebut, maka "kecelakaan" adalah kejadian yang tidak disengaja atau tidak disangka-sangka dengan akibat kematian, luka-luka atau kerugian benda Kecelakaan selalu mengandung unsur tidak disengaja atau tidak disangka-sangka dan menimbulkan rasa heran atau (tercengang terlebih dahulu) maka ini menimbulkan kecelakaan lalu lintas dan jika tabrakan yang dilakukan dengan sengaja atau direncanakan lebih dahulu itu mengakibatkan orang mati, maka perbuatan itu termasuk pembunuhan (Djajoesman, 2016).

Karakteristik kecelakaan menurut jumlah kendaraan yang terlibat digolongkan menjadi Kecelakaan tunggal, yaitu kecelakaan yang hanya melibatkan satu kendaraan bermotor dan tidak melibatkan pemakai jalan lain, contohnya seperti menabrak pohon, kendaraan tergelincir, dan terguling akibat ban pecah; Kecelakaan ganda, yaitu kecelakaan yang melibatkan lebih dari satu kendaraan atau kendaraan dengan pejalan kaki yang mengalami kecelakaan di waktu dan tempat yang bersamaan (Adelaide, 2012).

Faktor penyebab kecelakaan lalu lintas dapat dikelompokkan dalam empat unsur, yakni manusia, kendaraan, jalan, dan lingkungan. Secara umum ada tiga faktor utama penyebab kecelakaan; faktor pengemudi (road user), faktor kendaraan (vehicle), dan faktor lingkungan jalan (road environment). Kecelakaan yang terjadi pada umumnya tidak hanya disebabkan oleh satu faktor saja, melainkan hasil interaksi antar faktor lain. Hal-hal yang tercakup dalam faktor-faktor tersebut antar lain: faktor pengemudi, yaitu kondisi fisik (mabuk, lelah, sakit, dan sebagainya), kemampuan mengemudi, penyebrang atau pejalan kaki yang lengah, dan lain-lain. Faktor kendaraan yaitu, kondisi mesin, rem, lampu, ban, muatan, dan lain-lain. Faktor lingkungan jalan yaitu, desain jalan (median, gradien, alinyemen, jenis permukaan, dan sebagainya), kontrol lalu lintas (marka, rambu, lampu lalu lintas). Faktor cuaca yaitu, hujan, kabut, asap, salju, dan lainlain. Pada dasarnya faktor-faktor tersebut berkaitan atau saling menunjang bagi terjadinya kecelakaan. Namun, dengan diketahuinya faktor penyebab kecelakaan yang utama dapat ditentukan langkah-langkah penanggulangan untuk menurunkan jumlah kecelakaan.

Kecelakaan di jalan raya yang menyebabkan korban luka dan meninggal dari waktu jumlahnya tak surut. Setiap tahun penyebab kecelakaan lalu lintas di jalan raya semakin banyak dan bahkan mengakibatkan matinya orang. Penyebab terbesar dari kecelakaan bermacammacam, mulai dari menenggak minuman beralkohol, cuaca, masalah komponen mobil, hingga menelepon saat mengemudi. Hal ini dapat dilihat berdasarkan tabel di bawah ini tentang jumlah kecelakaan lalu lintas yang terus meningkat:

Tabel 1. Kecelakaan Lalu Lintas Tahun 2018 - 2020 Di Sat.Lantas Polres Humbang Hasundutan

\begin{tabular}{lllll}
\hline Tahun & Jumlah Kecelakaan & Korban Luka Ringan & Korban Luka Berat & Meninggal Dunia \\
\hline 2018 & 50 & 20 & 13 & 17 \\
\hline 2019 & 59 & 19 & 15 & 25 \\
\hline
\end{tabular}

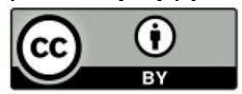


Dahnial Saragih, Taufik Siregar \& Rizkan Zulyadi. Kebijakan Hukum Dalam Upaya Penanggulangan

\begin{tabular}{lllll}
\hline 2020 & 38 & 12 & 10 & 16 \\
\hline
\end{tabular}

Sumber: Sat.Lantas Polres Humbang Hasundutan

Berdasarkan data tabel 1, kecelakaan lalu lintas yang yang terjadi hanya meningkat sedikit pada Tahun 2019, tetapi untuk korban luka berat dan meninggal dunia akibat kecelakaan lalu lintas mengalami peningkatan di Tahun 2019 dan penurunan di tahun 2020, sementara untuk korban kecelakaan lalu lintas dengan luka ringan juga sama. Dampak yang ditimbulkan akibat kecelakaan lalu lintas dapat menimpa sekaligus atau hanya beberapa diantaranya. Dampak tersebut dapat berupa materi dan korban jiwa.

Kecelakaan lalu lintas bisa di pengaruhi oleh faktor jalan, seperti permukaan jalan yang tidak rata, lampu jalanan yang kurang memadai, dan jalan yang berlubang. Memang ini menjadi tanggung jawab pemerintah untuk menyelesaikannya, namun kita sebagai pengguna jalan lebih baik mengantisipasi dengan lebih waspada agar tidak terjadi kecelakaan di jalan. Faktor jalan menjadi salah satu menjadi penyebab terjadinya kecelakaan lalu lintas bisa di lihat dari beberapa hal yaitu; ukuran jalan yang tidak mendukung dengan jumlah kendaraan yang semakin meningkat; Kondisi jalan banyak yang berlobang-lobang; Banyak jalan raya dijadikan sebagai tempat parkir sembarangan dan banyak jalan raya yang dipakai para pedagang untuk berjualan sehingga terjadinya penyempitan; Di jalan tersebut memiliki tikungan yang tajam sehingga menghalangi pandangan pengemudi. Secara garis besar keterkaitan dengan masalah keselamatan lalu lintas dapat dibahas dari dua lingkup: keselamatan primer (Primer Safety) atau Keselamatan aktif (Active Safety) dan keselamatan sekunder (Secondary Safety) atau keselamatan pasif (Passive Safety).

Keselamatan Primer ditekankan pada upaya pencegahan kecelakaan lalu lintas, sedangkan keselamatan sekunder ditekankan pada upaya untuk pencegahan timbulnya korban akibat kecelakaan lalu lintas (crashworthiness) itu sendiri (Tjahjono, 2011). Faktor Lingkungan / Alam seperti kondisi cuaca buruk sangat mempengaruhi kelancaran arus lalu lintas, bahkan dalam berbagai peristiwa, kecelakaan lalu lintas disebabkan oleh cuaca buruk. Maka faktor lingkungan dalam hal kaitannya dengan kecelakaan lalu lintas adalah disebabkan oleh cuaca, hujan deras, petir, kabut yang tebal sehingga mengurangi jarak pandang yang bebas terhadap kendaraan yang melintas. Oleh karena itu selain pengemudi/kendaraan dan keadaan jalan faktor alam juga menentukan penyebab terjadinya kecelakaan lalu lintas.

\section{Upaya Penanggulangan Tindak Pidana Kecelakaan Lalu Lintas Yang Mengakibatkan Matinya Korban}

Upaya penanggulangan kejahatan yang integral mengandung konsekuensi, bahwa segala usaha yang rasional untuk menanggulanginya harus merupakan satu kesatuan yang terpadu (integralitas), yang berarti kebijakan penanggulangan kejahatan dengan menggunakan upaya penal harus pula dipadukan dengan kebiasaan atau usaha-usaha yang bersifat non penal. Upaya penanggulangan dalam tindak pidana kecelakaan lalu lintas dapat berupa upaya penal dan non penal. Upaya penal, atau disebut "penal policy" menurut Marc Ancel adalah suatu ilmu sekaligus seni yang bertujuan untuk memungkinkan peraturan hukum positif dirumuskan secara lebih baik, atau disebut juga kebijakan hukum pidana (Arief, 2005). Penanggulangan kecelakaan lalu lintas oleh polisi dalam kebijakan hukum pidana adalah dengan melakukan tugas dan wewenangnya sebagai penyelidik dan penyidik untuk mencari terang tindak pidana yang terjadi dan menemukan tersangkanya, yang selanjutnya dilakukan penangkapan, penahanan, penyitaan barang bukti, pemeriksaan, serta pemberkasan untuk dikirim ke Jaksa Penuntut Umum (JPU), agar pelaku tindak pidana kelalaian mengakibatkan orang lain meninggal dunia dapat diproses dalam sidang pengadilan dan mendapatkan hukuman sebagaimana perbuatannya.

Menurut Sudarto, yang dimaksud dengan upaya represif adalah segala tindakan yang dilakukan oleh aparat penegak hukum sesudah terjadinya kejahatan atau tindak pidana, termasuk upaya represif adalah penyelidikan, penuntutan sampai dilakukannya pidana (Sudarto, 2006). Upaya represif yang dilakukan oleh aparat penegak hukum adalah: Melakukan tindakan 为 $h$ http://mahesainstitute.web.id/ojs2/index.php/jehss (N) mahesainstitut@gmail.com 1241

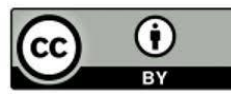

This work is licensed under a Creative Commons Attribution 4. 
hukum secara tegas dan profesioanal, prosedural, proporsional/ terukur dan humanis sesuai ketentuan peraturan perundang-undangan yang berlaku; Hindari arogansi dan tindakantindakan kekerasan terhadap tersangka terutama terhadap saksi; Melakukan koordinasi dengan kejaksaan dan pengadilan untuk proses penanganan kasus.

Proses penanggulangan terjadinya tindak pidana kecelakaan lalu lintas yang mengakibatkan matinya korban di wilayah hukum Resor Humbang Hasundutan diupayakan adanya perdamaian berupa mediasi. Mediasi merupakan suatu cara yang sering digunakan oleh seluruh pihak yang terlibat dalam suatu kecelakaan lalu lintas yang pada akhirnya menemukan kata mufakat untuk menyelesaikan perkara tersebut dengan cara kekeluargaan tanpa harus diselesaikan melalui proses hukum yang dilakukan dengan mempertemukan korban dan pelaku. Setelah dipertemukan, maka dilakukanlah mediasi yang diakhiri dengan kesepakatan perdamaian. Apabila telah tercapai perdamaian maka perkara kecelakaan lalu lintas dinyatakan selesai tanpa dilanjutkan ke proses peradilan pidana yang sesuai dengan peraturan perundangundangan (Mertokusumo, 2009).

Polri mengeluarkan Surat Edaran Kapolri Nomor: SE/8/VII/2018 tentang Penerapan Keadilan Restoratif (Restorative Justice) Dalam Penyelesaian Perkara Pidana, yang mengatur bahwa perkara yang dapat diselesaikan melalui mekanisme keadilan restoratif adalah perkara pidana dengan kerugian kecil yang merupakan kategori tindak pidana ringan, dan tidak dapat diterapkan terhadap tindak pidana berat yang mengakibatkan korban manusia. Selain itu, penerapan keadilan restoratif hanya dapat dilakukan terhadap tindak pidana sebelum Penyidik mengirim Surat Pemberitahuan Dimulainya Penyidikan (SPDP) ke Jaksa Penuntut Umum. Dengan demikian, penyelesaian perkara kecelakaan lalu lintas berat dengan korban meninggal dunia melalui keadilan restoratif yang dilakukan oleh Penyidik Satuan Lalu Lintas Polres Humbang Hasundutan berbanding terbalik dengan ketentuan dalam Surat Edaran Kapolri tersebut sehingga terjadi kesenjangan antara apa yang seharusnya (das sollen) dan apa yang menjadi kenyataan (das sein).

Pada dasarnya aparat penegak hukum didalam melaksanakan tugas kewajibannya selalu berpegang pada perundang-undangan yang berlaku (Hamzah, 2009). Selaku penegak hukum akan menegakkan semua ketentuan hukum yang berlaku, hal ini memang karena kewajibannya. Namun disamping selaku penegak hukum tugas polisi adalah pembina kamtibmas didaerahnya, dalam hal ini kebijakan-kebijakan yang dapat menyeimbangkannya kepada semua tugas itu selalu menjadi perhatian utama. Sehingga mau tidak mau di dalam melaksanakan tugas selalu ditempuh berbagai cara yang tepat.

Berdasarkan upaya non penal, tindakan preventif adalah tindakan-tindakan yang dilakukan oleh pihak kepolisian dengan maksud untuk pencegahan agar tidak terjadinya satu kejahatan. Penanggulangan kecelakaan lalu lintas oleh penegak hukum dapat dikelompokkan menjadi 3 (tiga) aspek yaitu aspek rekayasa (engineering), aspek pendidikan dan aspek pengelolaan. Adapun langkah-langkah yang dilakukan pihak Sat.Lantas Polres Humbang Hasundutan adalah preventif dan represif:

Penegakan hukum bidang pencegahan (preventif) yang meliputi: Kegiatan pengaturan yaitu cara petugas Lalu Lintas memberitahukan kepada pemakai jalan bagaimana dan dimana mereka bergerak atau berhenti, terutama pada saat kemacetan dan keadaan darurat lainnya dengan menggunakan isyarat gerakan tangan, sempritan/ pluit maupun tanda-tanda lainnya; Penjagaan adalah suatu kegiatan pengawasan lalu lintas pada tempat-tempat tertentu yang diadakan sesuai kebutuhan, terutama bersifat pencegahan, memberikan perlindungan, pelayanan terhadap pengguna jalan; Pengawalan dan patroli adalah suatu kegiatan pengawasan lalu lintas terhadap arus lalu lintas dan pemakai jalan yang dilakukan dengan cara bergerak (mobiling) kegiatan tersebut dilakukan pada ruas jalan tertentu berdasarkan analisis potensi kerawanan (rawan macet, rawan kecelakaan rawan pelanggaran lalu lintas) (Zulyadi, 2020). Dan pengawalan adalah kegiatan penyelanggaraan pelayanan dan pengamanan dalam rangka melindungi pergerakan/ perjalanan dari satu tempat ketempat lain dari suatu kegiatan masyarakat dan kewargaraan

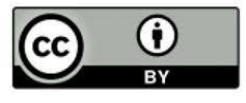


dengan menggunakan kendaran bermotor, pengawalan bertujuan agar pergerakan/ perjalanan yang dilakukan dapat berjalan dengan aman, tertib dan lancar.

Penegakan hukum bidang penertiban (represif) meliputi penertiban pelanggaran dan penyidikan kecelakaan lalu lintas: Penertiban pelanggaran lalu lintas dapat dilakukan secara: Edukatif yaitu memberikan teguran dan peringatan dengan cara simpatik terhadap para pelanggar lalu lintas; Yuridis adalah penertiban dengan menggunakan tilang dan atau menggunakan berita acara singkat/ sumir/ tipiring atau dengan berita acara biasa terhadap pelanggaran yang berpotensi atau memiliki bobot sangat fatal/ berat dan dapat merusak fasifitas umum (putusnya jembatan dan lain-lain); Penyidikan terhadap kecelakaan lalu lintas yang meliputi sejak penanganan TPTKP (Tindakan Pertama Tempat Kejadian Perkara), olah TKP (Tempat Kejadian Perkara), perneriksaan dan pemberkasan serta pengajuan ke sidang pengadilan maupun mengajukan permohonan klaim asuransi.

Penegakan hukum lalu lintas sebagai bentuk kegiatan upaya represif dilakukan terhadap setiap pemakai jalan yang melanggar hukum lalu lintas dan angkutan jalan, apabila dengan tindakan edukatif yang dilakukan dengan upaya pre-emtif dan prefentif tidak dapat menanggulangi masalahnya. Penegakan hukum yang dilakukan secara efektif dan intensif, pada hakekatnya bukan semata-mata ditujukan untuk memberikan pelajaran secara paksa atau untuk menghukum kepada setiap pelanggar yang tertindak, namun juga dimaksudkan untuk menimbulkan kejerahan bagi yang bersangkutan agar tidak mengulangi perbuatan lagi (Ilyas, 2012). Dengan demikian setiap penindakan represif juga mengandung unsur preventif. Sehubungan dengan upaya represif ini, perlu disadari bersama bahwa keberhasilan upaya penanggulangan keselamatan lalu lintas melalui penindakan tidak dapat bertumpuh hanya pada keaktifan aparat penegak hukum saja, melainkan harus diperhatikan pula faktorfaktor lainnya seperti pemakai jalan yang disiplin dan mentaati semua peraturan yang berlaku yang sangat berpengaruh terhadap keberhasilan penegak hukum (Akhbar, Dkk, 2019).

Upaya penanggulangan tindak pidana kecelakaan lalu lintas yang mengakibatkan matinya korban di Sat.Lantas Polres Humbang Hasundutan adalah dengan: Melakukan sosialisasi dengan masyarakat secara rutin; Memasang rambu-rambu rawan laka; Kordinasi dengan Dishub tentang pengadaan marka jalan; Koordinasi Dengan instansi pemerintah terkait tentang upaya penanggulangan tentang Lakalantas.

Tidak hanya itu, peran serta masyarakat sangat dibutuhkan untuk menggali sebuah informasi-informasi penting yang harus digali dari sebuah kasus kecelakaan lalu lintas. Untuk itu masyarakat dihimbau bila ada suatu kejadian penanganan terhadap pelaku pelanggaran lalu lintas yang melarikan diri atau kejahatan-kejahatan lain, atau mungkin jika masyarakat mengetahui jika akan ada suatu potensi untuk melakukan kejahatan tindak pidana yang lain, masyarakat dihimbau segera mungkin untuk melaporkan kepada pihak kepolisian terdekat. Karena wajib hukumnya masyarakat untuk melaporkan kepada pihak kepolisian jika ada peristiwa penanganan terhadap pelaku pelanggaran lalu lintas yang melarikan diri, sebab bila tidak dilaporkan maka mereka dapat ditahan (berkaitan dengan tindak pidana umum, laporan tidak bisa dicabut kembali). Oleh karena itu peran serta aktif dari masyarakat sangat dibutuhkan.

\section{SIMPULAN}

Aturan hukum terhadap pelaku tindak pidana kecelakaan lalu lintas yang mengakibatkan matinya korban diatur pada Pasal 359 Kitab Undang-Undang Hukum Pidana, Pasal 106 ayat (2), Pasal 229, Pasal 310 ayat 1 sampai 4 dan Pasal 312 Undang-Undang No. 22 Tahun 2009 tentang Lalu Lintas dan Angkutan Jalan dan Peraturan Pemerintah Nomor 37 Tahun 2017 Tentang Keselamatan Lalu lintas dan Angkutan Jalan. Pertanggungjawaban pelaku tindak pidana kecelakaan lalu lintas yang mengakibatkan matinya korban di Sat.Lantas Polres Humbang Hasundutan dilakukan dengan upaya penal yaitu pertanggungjawaban dengan hukuman pidana penjara yang diatur sesuai Pasal 310 ayat (4) Setiap orang yang mengemudikan Kendaraan Bermotor yang karena kelalaiannya mengakibatkan Kecelakaan Lalu Lintas yang mengakibatkan orang lain meninggal dunia dipidana penjara paling lama 6 (enam) tahun dan/atau denda paling 触http://mahesainstitute.web.id/ojs2/index.php/jehss 1243

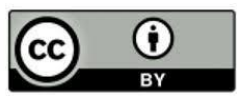

This work is licensed under a Creative Commons Attribution 4. 
banyak Rp. 12.000.000,00 (dua belas juta rupiah). Kebijakan hukum dalam upaya penanggulangan tindak pidana kecelakaan lalu lintas yang mengakibatkan matinya korban di Sat.Lantas Polres Humbang Hasundutan dilakukan secara Penal, Namun dalam tindak pidana kecelakaan lalu lintas yang mengakibatkan matinya korban diupayakan dulu mediasi penal yaitu perdamaian, antara pihak pelaku dan korban maupun keluarga korban, meskipun upaya perdamaian tetap melanjutkan proses hukum pidananya. Upaya hukum Non Penal yaitu: Upaya preventif adalah upaya-upaya yang ditujukan untuk mencegah terjadinya kecelakaan lalu lintas, yang dalam bentuk konkritnya berupa kegiatan-kegiatan pengaturan lalu lintas, penjagaan tempat-tempat rawan, patroli dan pengawalan. Mengingat bahwa kecelakaan lalu lintas terjadi karena faktor manusia, kendaraan, jalan dan lingkungan secara simultan maka upaya-upaya pencagahannya pun dapat ditujukan kepada pengaturan komponen-kompenen lalu lintas serta sistem lalu lintasnya. Upaya represif (penanggulangan), berupa penindakan terhadap setiap bentuk pelanggaran kasus kecelakaan lalu lintas. Upaya represif pada hakikatnya dalam rangka melindungi kecelakaan lalu lintas merupakan upaya akhir yang biasanya disertai dengan upaya penerapan paksa. Tindakan represif dilakukan terhadap setiap jenis pelanggaran lalu lintas atau dalam bentuk pelanggaran kasus kecelakaan lalu lintas.

\section{DAFTAR PUSTAKA}

Akhbar, A.T.F, Maswandi \& Kartika A. (2019). Perlindungan Hukum Bagi Anak Dalam Tindak Pidana Pencurian Dengan Kekerasan Yang Mengakibatkan Matinya Korban (Studi Putusan No. 37/Pid.SusAnak/2017/PN. Mdn). JUNCTO, 1(2) 2019: 183-192,

Arif, B.N, (2005), Beberapa Aspek Kebijakan Penegakan dan Pengembangan Hukum Pidana, PT Citra Aditya Bakti, Bandung.

Djajoesman S, (2016), Polisi dan Lalu Lintas, Pustaka Yustisia, Lembang.

Ediwarman, (2016), Monograf Metodologi Penelitian Hukum, Panduan Penulisan Skripsi, Tesis dan Disertasi, PT. Soft Media, Medan.

Effendy, M, (2014), Teori Hukum Murni Dari Perspektif Kebijakan, Perbandingan dan Harmonisasi Hukum Pidana, Gaung Persada Press Group, Jakarta.

Hadikusuma, H, (2006), Metode Pembuatan Kertas Kerja atau Skripsi Ilmu Hukum, Mandar Maju, Bandung. Hamzah, A, (2009), Kejahatan Terhadap Nyawa, PT. Rineka Cipta, Jakarta.

Ilyas, A, (2012), Asas-asas Hukum Pidana, Rangkang Education, Yogyakarta.

Marpaung, L, (2005), Asas-asas, Teori, Praktik Hukum Pidana. Sinar Grafika, Jakarta.

Marzuki, P.M, (2011), Penelitian Hukum Edisi Revisi, Prenada Media Group, Jakarta.

Mertokusumo, S, (2009), Mengenal Hukum Suatu Pengantar, Liberty. Yogyakarta.

Moeljatna, (2015), Asas-Asas Hukum Pidana, Rineka Cipta. Jakarta.

Nasution, B.J, (2011), Metode Penelitian Ilmu Hukum, Mandar Maju, Bandung.

Peraturan Kapolri No. 15 Tahun 2013 Tentang Tata Cara Penanganan Kecelakaan Lalu Lintas

Peraturan Pemerintah Nomor 37 Tahun 2017 Tentang Keselamatan Lalu lintas dan Angkutan Jalan

Praja, S.J, (2014), Teori Hukum dan Aplikasinya, CV. Pustaka Setia. Bandung.

Prodjodikoro, W, (2013), Asas-Asas Hukum Pidana di Indonesia, Refika Aditama, Bandung

Raharjo, R (2014), Tertib Lalu Lintas, Shafa Media, Yogyakarta.

Sodikin, A, (2007), Restorative Justice dalam Tindak Pidana Pembunuhan, Alumni, Bandung.

Soesilo, R, (2014), Kitab Undang-Undang Hukum Pidana (KUHP) serta KomentarKomentarnya Lengkap Pasal demi Pasal, Politeia, Bogor.

Sudarto, (2006), Hukum dan Hukum Pidana, Alumni, Bandung.

Suharjo, J.B, (2012), Gaya Hidup dan Penyakit Modern, Cetakan V, Kanisius, Yogyakarta.

Surat Edaran Kapolri Nomor: SE/7/VII/2018 tentang penghentian penyelidikan

Surat Edaran Kapolri Nomor: SE/8/VIII/2018 tanggal 27 Juli 2018 tentang Penerapan Keadilan Restoratif

(Restorative Justice) Dalam Penyelesaian Perkara Pidana.

Syarifin, P, (2010), Hukum Pidana di Indonesia, Pustaka Setia, Bandung.

Tjahjono, T, (2011), Analisis Keselamatan Lalu Lintas, Lubuk Agung, Bandung.

Undang-Undang No. 1 Tahun 1946 Tentang Kitab Undang-Undang Hukum Pidana

Undang-Undang No. 38 tahun 2004 tentang Jalan

Undang-Undang No. 8 Tahun 1981 tentang Kitab Undang-Undang Hukum Acara Pidana

Undang-Undang RI Nomor 22 Tahun 2009 tentang Lalu Lintas dan Angkutan Jalan

Warpani, S.P, (2012), Pengelolaan Lalu Lintas dan Angkutan Jalan, Penerbit ITB, Bandung

12htt//mahesainstitute.web.id/ojs2/index.php/jehss

ॠmahesainstitut@gmail.com

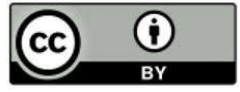

This work is licensed under a Creative Commons Attribution 4.0 
Dahnial Saragih, Taufik Siregar \& Rizkan Zulyadi. Kebijakan Hukum Dalam Upaya Penanggulangan

Wijayanti, A, (2011), Strategi Penulisan Hukum, Lubuk Agung, Bandung.

Zulyadi, R. (2020). Kerangka Teori Dalam Penelitian Hukum. Medan: Enam Media. 